\title{
Treatment of Acidic Petroleum Crude Oil Utilizing Catalytic Neutralization Technique of Magnesium Oxide Catalyst
}

Norshahidatul Akmar Mohd Shohaimi, Wan Azelee Wan Abu Bakar*, Jafariah Jaafar and Nurasmat Mohd Shukri

Department of Chemistry, Universiti Teknologi Malaysia, Malaysia

\begin{abstract}
The presence of naphthenic acids in crude oils has caused a major corrosion problem to the production equipment, storage and transport facilities in the petroleum industry. The level of acidity of crude oil was determined by the value of Total Acid Number (TAN) in the oil samples. Two types of crude: Petronas Penapisan Melaka Heavy Crude and Petronas Penapisan Melaka Light Crude were studied. Various parameters studied were the amount of chemical dosing, type of catalyst, different catalyst calcination temperatures, and catalyst ratio of basic metal and dopant. The basic chemical used was ammonia solution in ethylene glycol $\left(\mathrm{NH}_{3}-\mathrm{EG}\right)$ with a concentration range of 100-1000 mg/L.

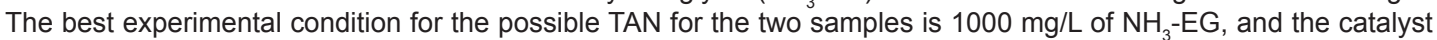
reaction must be in the range of $35-40^{\circ} \mathrm{C}$. Cu/Mg (10:90)/Al $\mathrm{O}$, catalyst successfully reduced TAN in Heavy Crude for about $84.8 \%$ while for Light Crude, TAN was reduced $66.7 \%$ with the aids of $\mathrm{Ni} / \mathrm{Mg}(10: 90) / \mathrm{Al}_{2} \mathrm{O}_{3}$ catalyst. Increase concentration of basic chemical, reduced the total acid number value of both crude oil.
\end{abstract}

Keywords: Naphthenic acid; Crude oil; Catalyst; Total acid number

\section{Introduction}

Naphthenic acid consist of saturated acyclic, monocyclic and polycyclic carboxylic acids with the general chemical formula of $\mathrm{C}_{\mathrm{n}} \mathrm{H}_{2 \mathrm{n}+\mathrm{Z}} \mathrm{O}_{2}$; where $\mathrm{n}$ is the carbon number and $\mathrm{Z}$ represents the hydrogen atoms lost as the structures form rings [1]. Naphthenic acid problem had become a great concern to petroleum industry nowadays because of the corrosive properties of naphthenic acid tends to cause aggravated equipment corrosion, especially at high temperature $\left(230-400^{\circ} \mathrm{C}\right)$, and this leads to high maintenance costs, may pose environmental disposal problems and low quality of the crude oils produced. There is no clear consensus on what constitutes a dangerous concentration of naphthenic acids, but corrosion will occur if the neutralization number is above 0.5 $\mathrm{mg} \mathrm{KOH} / \mathrm{g}$ of crude $[2,3]$. Therefore, any reduction in naphthenic acids content would alleviate corrosion related problems.

Many efforts had been done in order to remove or lowered down the naphthenic acid value in crude oil such as by catalytic decarboxylation [4] addition of caustic, blending, neutralization by caustic addition [5], blending petroleum crude oils with ionic liquid of ethanol [6], by adding solid acid catalyst and metal oxide catalyst [7]. But, these methods have their own drawbacks that created many problems and lead to high maintenance cost. Zhang et al. had study on the removal of naphthenic acid by ammonia solution in ethylene glycol, but that method required longer extraction time and the technique was a bit complicated [8]. Thus, the concern of this research is to formulate a simple catalytic neutralization technique utilizing a chemical base solution together with the aid of an alumina supported alkaline earth metal catalyst, in order to neutralized and remove the naphthenic acids to reduce the TAN lower than a value of one.

\section{Problem statement}

Naphthenic acid currently become the main issue in the refineries unit as it is one of the factors that contribute to the corrosion problem. High value of TAN lead to highly acidic crude oils that affected the quality of oils produced and contributed to the low performance of operations unit. This leads to high maintenance costs, and may create environmental disposal problems. So far, no research has been done to fabricate a specific chemical base solution and an effective catalyst to remove the naphthenic acids in crude oils. Hence, this study was executed to remove the naphthenic acid in crude oils using ammonia solution of ethylene glycol with the aid of alkaline earth metal catalyst.

\section{Experimental}

\section{Preparation of catalysts}

Magnesium based catalyst with dopant of Nickel and Copper will be studied. The ratio of based-dopant used were 10(dopant):90(based) and 30(dopant):70(based). Various calcination temperatures used were $400^{\circ} \mathrm{C}, 700^{\circ} \mathrm{C}$ and $1000^{\circ} \mathrm{C}$. The metal precursors used in this research are nitrate salt. Generally, all the samples in this research were prepared by aqueous incipient wetness impregnation method [9]. Each of metal salts was weighed in a beaker according to the desired ratio and dissolved it in small amount of distilled water. The magnesium loading used was 90 $w t \%$. Then, the solutions were mixed together and stirred continuously by magnetic bar for 30 minutes at room temperature to homogenize the mixture. In $\mathrm{Mg}$ based catalyst, $\mathrm{Al}_{2} \mathrm{O}_{3}$ is the most widely used support material. Thus, alumina beads with diameter of $4 \mathrm{~mm}$ to $5 \mathrm{~mm}$ were used as support material in this study. The support was immersed into the catalysts solution for 1 hour and transferred the supported catalysts onto evaporating dish with glass wool on it. It was then aging inside an oven at $80-90^{\circ} \mathrm{C}$ for 24 hours to remove water and allow good coating of the metal on the surface of the supported catalysts. It was then followed by calcination in the furnace at $400^{\circ} \mathrm{C}$ for 5 hours using a ramp rate of $5^{\circ} \mathrm{C} / \mathrm{min}$ to eliminate all the metal precursor and excess of water or impurities. Similar procedure was repeated for the other ratio and calcination temperature of catalysts.

\section{Catalysts characterization}

Potential catalyst was characterized by several techniques to study its physical properties. The information obtained is highly useful in order to understand the relationship between the properties and its catalytic performance towards the neutralization activity. In this research, the

*Corresponding author: Wan Azelee Wan Abu Bakar, Professor, Department of Chemistry, Universiti Teknologi Malaysia, Malaysia, Tel: +6013-746-6213; E-mail: wazelee@kimia.fs.utm.my

Received April 05, 2013; Accepted April 22, 2013; Published April 29, 2013 Citation: Shohaimi NAM, Abu Bakar WAW, Jaafar J, Shukri NM (2013) Treatment of Acidic Petroleum Crude Oil Utilizing Catalytic Neutralization Technique of Magnesium Oxide Catalyst. Mod Chem appl 1: 103. doi:10.4172/2329-6798.1000103

Copyright: (C) 2013 Shohaimi NAM, et al. This is an open-access article distributed under the terms of the Creative Commons Attribution License, which permits unrestricted use, distribution, and reproduction in any medium, provided the original author and source are credited. 
Citation: Shohaimi NAM, Abu Bakar WAW, Jaafar J, Shukri NM (2013) Treatment of Acidic Petroleum Crude Oil Utilizing Catalytic Neutralization Technique of Magnesium Oxide Catalyst. Mod Chem appl 1: 103. doi:10.4172/2329-6798.1000103

characterization techniques used were X-Ray Diffraction Spectroscopy (XRD), Scanning Electron Microscopy (SEM), and Energy Dispersive X-Ray (EDX).

\section{Feedstock and basic chemical}

The feedstock used in this study was light and heavy crude obtain from Petronas Penapisan Melaka. Ammonia solution in ethylene glycol was prepared to be used as the base chemical in the acid base neutralization process. The concentrations of ammonia solution in ethylene glycol use are $100 \mathrm{mg} / \mathrm{L}, 500 \mathrm{mg} / \mathrm{L}$ and $1000 \mathrm{mg} / \mathrm{L}$.

\section{Preparation of ammonia solution in ethylene glycol}

$400 \mu \mathrm{L}$ of ammonia solution was added into $99.6 \mathrm{~mL}$ of ethylene glycol and stirred for about $15 \mathrm{~min}$. The solution is then stir vigorously for 1 hour and stored in the dark place to avoid sunlight's penetration. The solution is then ready to be blend with the crude oil samples.

\section{Total Acid Number (TAN) determination}

The petroleum crude oil samples were titrated with potassium hydroxide solution $(0.01 \mathrm{~mol} / \mathrm{L})$ with the addition of the developed base chemical to remove the organic acid present in crude oil. Prepared catalyst was also added in the solution to enhance the neutralization process. The indicator used was phenolphthalein solution where the stable red color was observed. The titration method was performed on two different types of crude oil samples which are PETRONAS Penapisan Melaka Light Crude and PETRONAS Penapisan Melaka Heavy Crude. In order to express the results, total acid number (TAN) of the sample was calculated in milligrams of potassium hydroxide per gram of sample $(\mathrm{mg} \mathrm{KOH} / \mathrm{g})$ by using this equation:

$$
\mathrm{TAN}=56.1 \times \mathrm{c} \times \frac{\left(\mathrm{V}_{\mathrm{KOH}}-\mathrm{V}_{\mathrm{B}}\right)}{\mathrm{m}}
$$

Where,

$\mathrm{c}=$ concentration, in moles per liter, of standard volumetric potassium hydroxide solution.

$\mathrm{V}_{\mathrm{KOH}}=$ volume, in milliliters, of titrant required for the determination.

$\mathrm{V}_{\mathrm{B}}=$ volume, in milliliters, of titrant required for the blank test.

$\mathrm{m}=$ mass, in grams, of the test portion .

\section{Results and Discussion}

\section{Characterization of the potential catalyst}

The most potential catalyst undergone characterization process utilizing XRD and SEM-EDX analysis. The most effective catalyst that reduced the total acid number in the both crude oils are $\mathrm{Cu} / \mathrm{Mg}(10: 90) /$ $\mathrm{Al}_{2} \mathrm{O}_{3}$. and $\mathrm{Ni} / \mathrm{Mg}(10: 90) / \mathrm{Al}_{2} \mathrm{O}_{3}$ which both calcined at $1000^{\circ} \mathrm{C}$

\section{Characterization process using $\mathrm{X}$-ray diffraction}

Figures 1 and 2 show the XRD diffractograms of $\mathrm{Cu} / \mathrm{Mg}(10: 90) /$ $\mathrm{Al}_{2} \mathrm{O}_{3}$ and $\mathrm{Ni} / \mathrm{Mg}(10: 90) / \mathrm{Al}_{2} \mathrm{O}_{3}$ catalysts calcined at 400, 700, and $1000^{\circ} \mathrm{C}$ for 5 hours. All diffractograms illustrates the catalysts $\mathrm{Cu} / \mathrm{Mg}$ (10:90)/ $\mathrm{Al}_{2} \mathrm{O}_{3}$ and $\mathrm{Ni} / \mathrm{Mg}(10: 90) / \mathrm{Al}_{2} \mathrm{O}_{3}$ catalyst are highly amorphous, lack of periodicity and it have short range order. With increase of calcinations temperature also increase the intensity of the characteristic lines. From the diffraction patterns of both catalysts calcined at 400, 700 and those calcined at $1000^{\circ} \mathrm{C}$, it can be suggested that the phase is dominated by $\mathrm{Al}_{2} \mathrm{O}_{3}$ cubic phase at $2 \theta$ values of $37.682^{\circ}, 45.845^{\circ}$ and $66.845^{\circ}$ with $\mathrm{d}$ spacing values of $2.385,1.978$ and $1.398 \AA$ was observed as seen in figures 1 and 2 all of the peaks assignment of $\mathrm{Al}_{2} \mathrm{O}_{3}$ in the diffractograms remained almost unchanged. Based on figure 1 Cubic $\mathrm{CuO}$ was revealed at $2 \theta$ values of $42.559^{\circ}$ with $\mathrm{d}$ spacing values of 2.123 $\AA$. Besides that, $\mathrm{MgO}$ cubic phase was obtained at $2 \theta$ values of $42.95^{\circ}$ with $\mathrm{d}$ spacing value of $2.1064 \AA$. Rhombohedral phase $\mathrm{Al}_{2} \mathrm{O}_{3}$ was found at $2 \theta$ values of $57.497^{\circ}$ with $d$ spacing value of $1.602 \AA$. Figure 2 was only dominated by $\mathrm{Al}_{2} \mathrm{O}_{3}$ cubic phase at $2 \theta$ values of $37.682^{\circ}$, $45.845^{\circ}$ and $66.845^{\circ}$ with $\mathrm{d}$ spacing values of $2.385,1.978$ and $1.398 \AA$ The amorphous structure of figure 2 catalyst has made the $\mathrm{MgO}$ and $\mathrm{NiO}$ phase undetectable. The disappearance of $\mathrm{MgO}$ and $\mathrm{NiO}$ peak in XRD pattern was probably due to the small size $\mathrm{MgO}$ and $\mathrm{NiO}$ particles which was beyond the detection limit of XRD (detection limit of XRD $=4 \mathrm{~nm}$ ) or incorporation of $\mathrm{Mg}$ and $\mathrm{Ni}$ species into the bulk matrixes (Figures 1 and 2).

\section{Scanning Electron Microscope (SEM) Analysis}

Figure 3 shows the SEM micrographs of $\mathrm{Cu} / \mathrm{Mg}(10: 90) / \mathrm{Al}_{2} \mathrm{O}_{3}$ catalysts, and figure 4 show SEM images for $\mathrm{Ni} / \mathrm{Mg}(10: 90) / \mathrm{Al}_{2} \mathrm{O}_{3}$ catalysts calcined at 400,700 and $1000^{\circ} \mathrm{C}$ for 5 hours with magnification of 1000x. Both catalysts showed rough surface morphology with inhomogeneous spherical shape and comes with a mixture of small and large particles sizes. The micrograph shows that the particle is not well dispersed. The smaller particles size plays an important role to exhibit the higher catalytic activity.

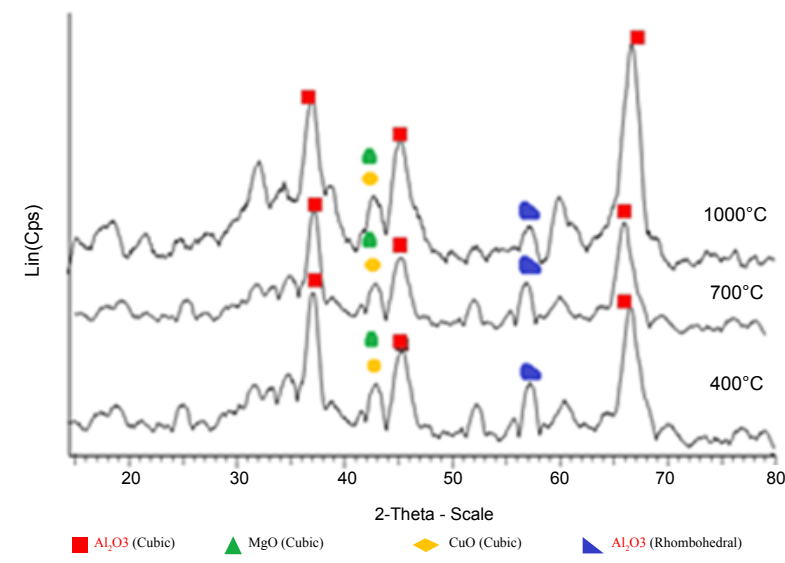

Figure 1: X-ray diffractogram of $\mathrm{Cu} / \mathrm{Mg}(10: 90) / \mathrm{Al} \mathrm{O}_{3}$ catalyst for calcinations temperatures of 400,700 and $1000^{\circ} \mathrm{C}$

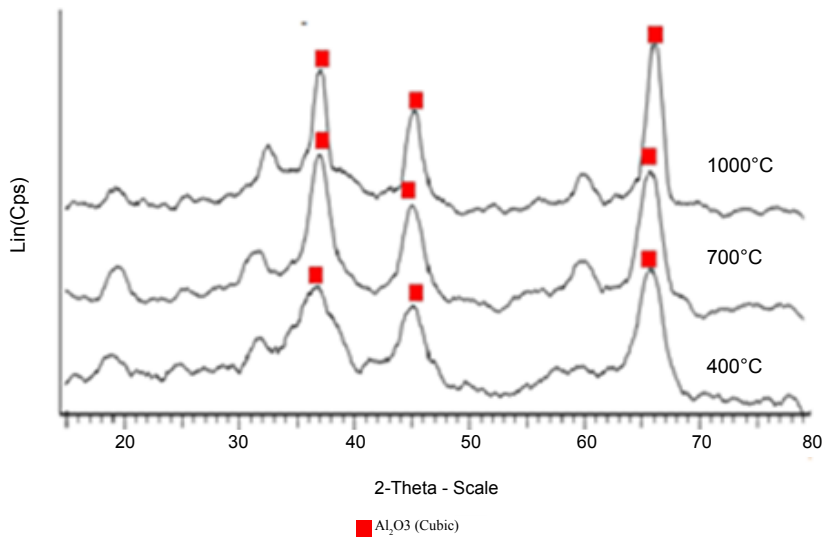

Figure 2: X-ray diffractogram of $\mathrm{Ni} / \mathrm{Mg}(10: 90) / \mathrm{Al}_{2} \mathrm{O}_{3}$ catalyst for calcination temperatures of 400,700 and $1000^{\circ} \mathrm{C}$. 
Citation: Shohaimi NAM, Abu Bakar WAW, Jaafar J, Shukri NM (2013) Treatment of Acidic Petroleum Crude Oil Utilizing Catalytic Neutralization Technique of Magnesium Oxide Catalyst. Mod Chem appl 1: 103. doi:10.4172/2329-6798.1000103

This result is relevant to the results of XRD analysis which appeared with very broad peaks denoting an amorphous state observed in the diffractogram calcined at $400^{\circ} \mathrm{C}$ caused by the very small of particle size. The smaller particle size of the catalyst will lead to a higher dispersion of the catalyst and large surface area of supported magnesium oxide based catalyst. It is little difficult to find out the particle size and morphology of the sample from this image (Figures 3 and 4).

\section{Energy Dispersive X-Ray analysis (EDX)}

EDX analysis provides useful information on the percentage of the elements present in the sample, as well as the percentage of catalyst over the support in order to see how much of the catalyst that has successfully coated the support. Table 1 illustrates that at calcination temperature of $1000^{\circ} \mathrm{C}$, the weight composition of $\mathrm{Mg}$ in the $\mathrm{Cu} / \mathrm{Mg}$ (10:90)/ $\mathrm{Al}_{2} \mathrm{O}_{3}$ catalyst is 9.32 , the highest compared to the catalysts calcined at temperature 400 and $700^{\circ} \mathrm{C}$.

Meanwhile, the table 2 shows that the amount of $\mathrm{Mg}$ in the $\mathrm{Ni} / \mathrm{Mg}$ (10:90)/ $\mathrm{Al}_{2} \mathrm{O}_{3}$ catalyst at calcination temperature of $1000^{\circ} \mathrm{C}$ was 10.28 higher than other in the different temperature. The elemental analysis performed by EDX confirmed the presence of $\mathrm{Mg}, \mathrm{Cu}, \mathrm{Ni}, \mathrm{Al}$, and $\mathrm{O}$ in the potential catalyst. Basically, the amount of support material have greater amount than metal as the support material play a role as to control, homogenize and to stabilize the metal oxide phases in the catalyst. From the elementally analysis, the results obtained indicated that element are in homogeneously distributed on the surface of the supported catalyst (Tables 1 and 2).

Formulated chemical base solution consists of ammonia solution of ethylene glycol

The ammonia solution of ethylene glycol with various concentrations

\begin{tabular}{|c|c|c|}
\hline $\begin{array}{c}\text { Calcination Temperature } \\
\left({ }^{\circ} \mathbf{C}\right)\end{array}$ & Element & $\begin{array}{c}\text { Weight Composition } \\
\mathbf{( \% )}\end{array}$ \\
\hline 400 & $\mathrm{Al}$ & 57.87 \\
\hline & $\mathrm{Mg}$ & 4.33 \\
\hline & $\mathrm{Cu}$ & 1.28 \\
\hline & $\mathrm{O}$ & 36.52 \\
\hline & $\mathrm{Al}$ & 50.32 \\
\hline & $\mathrm{Mg}$ & 7.20 \\
\hline & $\mathrm{Cu}$ & 6.46 \\
\hline & $\mathrm{O}$ & 36.02 \\
\hline & $\mathrm{Al}$ & 49.88 \\
\hline & $\mathrm{Mg}$ & 9.32 \\
\hline & $\mathrm{Cu}$ & 4.88 \\
\hline & $\mathrm{O}$ & 35.92 \\
\hline
\end{tabular}

Table 1: Elemental composition from EDX analysis for Cu/Mg (10:90)/ $\mathrm{Al}_{2} \mathrm{O}_{3}$ catalysts calcined at 400,700 , and $1000^{\circ} \mathrm{C}$.

\begin{tabular}{|c|c|c|}
\hline $\begin{array}{c}\text { Calcination Temperature } \\
\left({ }^{\circ} \mathbf{C}\right)\end{array}$ & Element & $\begin{array}{c}\text { Weight Composition } \\
(\mathbf{\%})\end{array}$ \\
\hline 400 & $\mathrm{Al}$ & 56.53 \\
\hline & $\mathrm{Mg}$ & 4.12 \\
\hline & $\mathrm{Ni}$ & 1.33 \\
\hline 700 & $\mathrm{O}$ & 38.02 \\
\hline & $\mathrm{Al}$ & 53.77 \\
\hline & $\mathrm{Mg}$ & 6.88 \\
\hline & $\mathrm{Ni}$ & 4.67 \\
\hline & $\mathrm{O}$ & 34.68 \\
\hline & $\mathrm{Al}$ & 50.73 \\
\hline & $\mathrm{Mg}$ & 10.28 \\
\hline & $\mathrm{Ni}$ & 4.92 \\
\hline & $\mathrm{O}$ & 34.07 \\
\hline
\end{tabular}

Table 2: Elemental composition from EDX analysis for $\mathrm{Ni} / \mathrm{Mg}(10: 90) / \mathrm{Al}_{2} \mathrm{O}_{3}$ catalysts calcined at 400,700 , and $1000^{\circ} \mathrm{C}$.

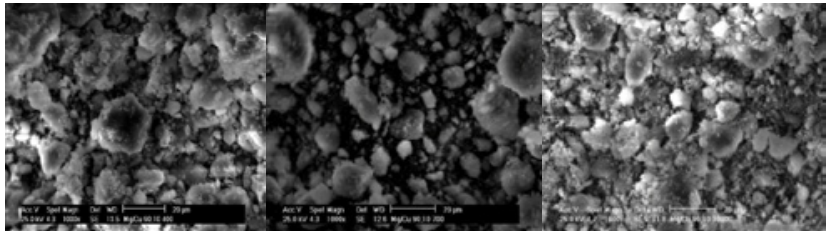

a) $400^{\circ} \mathrm{C}$

b) $700^{\circ} \mathrm{C}$

c) $1000^{\circ} \mathrm{C}$

Figure 3: SEM micrographs of $\mathrm{Cu} / \mathrm{Mg}(10: 90) / \mathrm{Al}_{2} \mathrm{O}_{3}$ catalysts, calcined at 400,700 and $1000^{\circ} \mathrm{C}$ for 5 hours with magnification of $1000 x$.

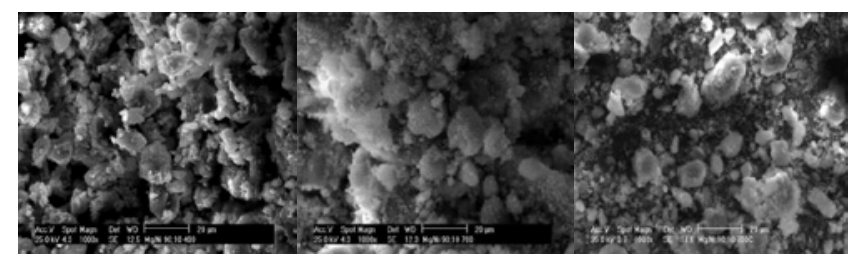

a) $400^{\circ} \mathrm{C}$

b) $700^{\circ} \mathrm{C}$

c) $1000^{\circ} \mathrm{C}$

Figure 4: SEM images for $\mathrm{Ni} / \mathrm{Mg}(10: 90) / \mathrm{Al}_{2} \mathrm{O}_{3}$ catalysts, calcined at 400,700 and $1000^{\circ} \mathrm{C}$ for 5 hours with magnification of $1000 \mathrm{x}$.

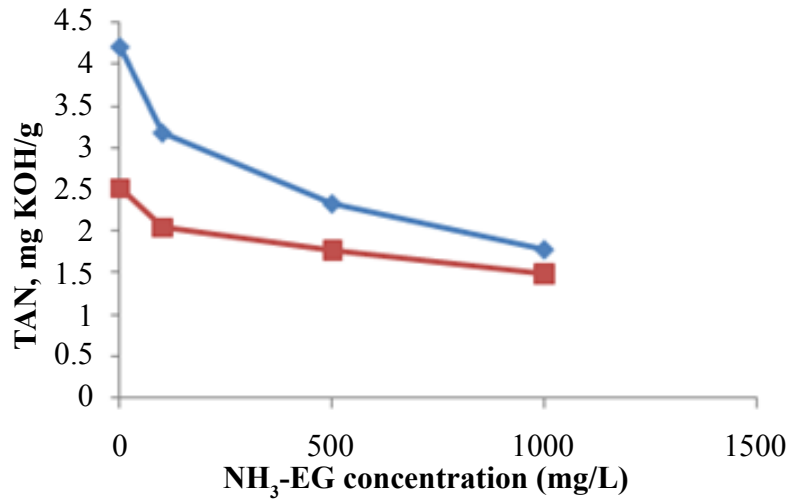

Figure 5: Effect of $\mathrm{NH}_{3}-\mathrm{EG}$ concentration to the TAN reduction for $(\diamond)$ CrudeA and ( $\square$ ) Crude B.

of 100,500 and $1000 \mathrm{mg} / \mathrm{L}$ were synthesized. Figure 5, shows that only small amount of naphthenic acids in crude oil was reduced when an ammonia solution of ethylene glycol was added at concentration of 100 , 500 and $1000 \mathrm{mg} / \mathrm{L}$.

Crude A is a heavy crude oil, the total acid number (TAN) in the crude oil was 4.21 . But, after treatment with $100 \mathrm{mg} / \mathrm{L}$ of ammonia solution, the number was reduced to 3.18 . The number was further decreased to 2.33 and 1.78 after added with 500 and $1000 \mathrm{mg} / \mathrm{L}$ of ammonia solution respectively.

Initially, without addition of ammonia solution of ethylene glycol, the total acid number (TAN) in the crude B which is light crude oil was 2.52. But, with addition of $100 \mathrm{mg} / \mathrm{L}$ of ammonia solution, the TAN was lowered to 2.05. TAN was decrease as the amount of ammonia solution is increase; this has been shown when the number of acid in crude $\mathrm{B}$ was decreased to 1.77 and 1.49 for 500 and $1000 \mathrm{mg} / \mathrm{L}$ of ammonia solution.

It can be concluded that only 57.72 percent of acid number in the crude A and 40.87 percent of crude B were reduced when treated 

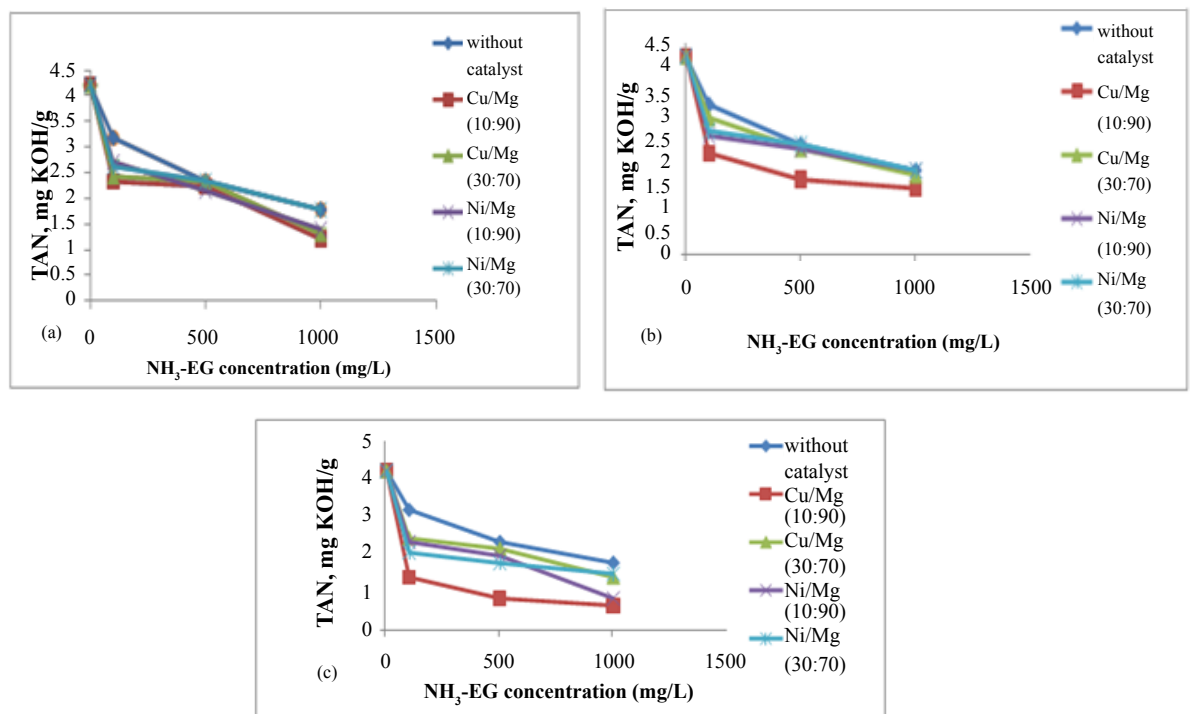

Figure 6: Effect of catalysts on the reduction of TAN for crude oil A with different calcination temperatures of (a) $400^{\circ} \mathrm{C},(\mathrm{b}) 700^{\circ} \mathrm{C}$ and (c) $1000^{\circ} \mathrm{C}$.
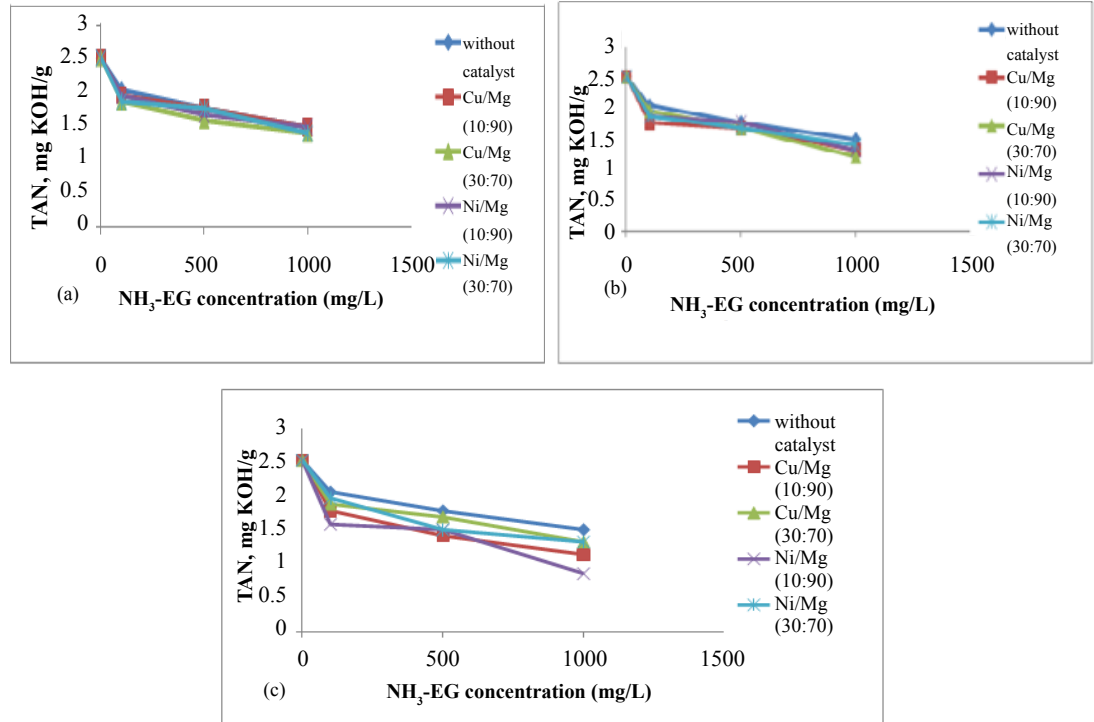

Figure 7: Effect of catalysts on the reduction of TAN for crude oil B with different calcination temperatures of (a) 400 , (b) 700 and (c) $1000^{\circ} \mathrm{C}$

with ammonia solution of ethylene glycol due to insufficient amount concentration added. Thus, in order to completely reduce the number of acid in both crude oil, the concentration of the ammonia solution must be greater than $1100 \mathrm{mg} / \mathrm{L}$ or by addition of catalysts.

\section{Catalytic activity of alkaline earth metal oxide catalyst}

The metal oxide catalysts had been used in this research study was a heterogeneous catalyst. The prepared catalyst with respect to each ratio and with different calcination temperature were brought to conduct the test involve of removal of naphthenic acid in the both crude oils utilizing ASTM D664 standard titration method. Figures 6a-6c illustrates the total acid number in Crude A (heavy crude) by using ammonia solution of ethylene glycol as a base chemical with the addition of a catalyst. As shown in this figure, the aim of the addition of the catalyst is to lower the total acid number through the catalytic decarboxylation reaction compared to the neutralization process without the addition of a catalyst.

From the plotted graphs, it's obviously shown that the most effective catalyst in the lowered down the acid number is $\mathrm{Cu} / \mathrm{Mg}(10: 90) / \mathrm{Al}_{2} \mathrm{O}_{3}$ calcined at a temperature of $1000^{\circ} \mathrm{C}$ since the number of total acid number is lowered than one which is 0.64 . Followed by Ni/Mg (10:90)/ $\mathrm{Al}_{2} \mathrm{O}_{3}, 1000^{\circ} \mathrm{C}$ and the least effective catalyst was $\mathrm{Ni} / \mathrm{Mg}(30: 70) / \mathrm{Al}_{2} \mathrm{O}_{3}$, at $700^{\circ} \mathrm{C}$. This proves that the higher the temperature, the activity of the catalyst also higher and the more favored the catalyst to convert the carboxyl compound to the carbon dioxide. Thus, enhance the catalytic decarboxylation process to occur (Figure 6).

Based on the figures $7 a-7 c$, the highly potential catalyst that can 
reduce the total acid number in Crude oil $\mathrm{B}$ to a TAN less than one is $\mathrm{Ni} / \mathrm{Mg}(10: 90) / \mathrm{Al}_{2} \mathrm{O}_{3}$, which calcined at $1000^{\circ} \mathrm{C}$. This catalyst reduced the TAN of Crude oil B from 2.52 to 0.84 . Next, is $\mathrm{Cu} / \mathrm{Mg}$ (30:70)/ $\mathrm{Al}_{2} \mathrm{O}_{3}$, calcined at $700^{\circ} \mathrm{C}$ which decrease the 51.98 percent of the number of acid in the crude oil $\mathrm{B}$. Thus, to make this possible for this catalyst to reduce TAN, the dose of ammonia solution of ethylene glycol must be higher. The ineffective catalyst for crude oils $\mathrm{B}$ is $\mathrm{Cu} / \mathrm{Mg}$ (10:90)/ $\mathrm{Al}_{2} \mathrm{O}_{3}$, due to the catalyst only activate at the high temperature of calcined and this catalyst still have impurities that cannot be remove at low temperature of calcination.

As per conclusion, the most preferable catalyst for lowered TAN in the crude oils $\mathrm{A}$ is $\mathrm{Cu} / \mathrm{Mg}(10: 90) / \mathrm{Al}_{2} \mathrm{O}_{3}$. Meanwhile, for crude $\mathrm{B}$ is $\mathrm{Ni} /$ $\mathrm{Mg}$ (10:90)/ $\mathrm{Al}_{2} \mathrm{O}_{3}$. These two catalysts were characterized to know its properties, which will be discussed further (Figure 7).

\section{Summary and Conclusion}

The research study has proven that the formulated chemical base solution consisting of ammonia solution of ethylene glycol and addition of alkaline earth metal oxides as catalyst had been successfully applied to neutralize and remove the acidic compound in the crude oil, thus reducing the total acid number (TAN) below than one. The TAN value decreased as the concentration of ammonia solution of ethylene glycol increased with the aid of a catalyst. In this study, it has been found that semi micro color titration method is one of the effective methods to determine the total acid number (TAN) in crude oil.

Catalytic decarboxylation was proven as an effective technique in the removal of naphthenic acids in the crude oil samples. In this study, the effective catalysts for both crude oil have been identified. For crude $\mathrm{A}$, the most effective catalyst is $\mathrm{Cu} / \mathrm{Mg}(10: 90) \mathrm{Al}_{2} \mathrm{O}_{3}$ and for crude $\mathrm{B}$, is $\mathrm{Ni} / \mathrm{Mg}(10: 90) \mathrm{Al}_{2} \mathrm{O}_{3}$. The calcination temperature for both catalysts was at $1000^{\circ} \mathrm{C}$.

The characterization of the potential catalyst has been achieved using XRD and SEM-EDX. From XRD diffractograms, it showed that both catalysts were highly amorphous while SEM images showed surface morphology with inhomogeneous spherical shape and appeared with a mixture of small and large particles sizes.

\section{Acknowledgements}

The authors would like to thank the Malaysian Ministry of Higher Education, Universiti Teknologi Malaysia for their financial funding through FRGS grant 78468 and research university grant $01 \mathrm{H} 58$.

\section{References}

1. Vaz de Campos MC, Oliveira EC, Filho PJ, Piatnicki CM, Caramao EB (2006) Analysis of tert-butyldimethylsilyl derivatives in heavy gas oil from Brazilian naphthenic acids by gas chromatography coupled to mass spectrometry with electron impact ionization. J Chromatogr A 1105: 95-105.

2. Huang M, Zhao S, Li P, Huisingh D (2006) Removal of naphthenic acid by microwave. Journal of Cleaner Production 14: 736-739.

3. Wang Y, Chu Z, Qiu B, Liu C, Zhang Y (2006) Removal of naphthenic acids from a vacuum fraction oil with an ammonia solution of ethylene glycol. Fue 85: 2489-2493.

4. Zhang A, Ma Q, Wang K, Liu X, Shuler P, et al. (2006) Naphthenic acid remova from crude oil through catalytic decarboxylation on magnesium oxide. Applied Catalysis A: General 303: 103-109.

5. Ding L, Rahimi P, Hawkins R, Bhatt S, Shi Y (2009) Naphthenic acid removal from heavy oils on alkaline earth-metal oxides and $\mathrm{ZnO}$ catalysts. Applied Catalysis A: General 371: 121-130.

6. Shi LJ, Shen BX, Wang GQ (2008) Removal of naphthenic acids from Beijiang crude oil by forming ionic liquids. Energy Fuels 22: 4177-4181.

7. Fu X, Dai Z, Tian S, Long J, Hou S, et al. (2008) Catalytic decarboxylation of petroleum acids from high acid crude oils over solid acid catalysts. Energy Fuels 22: 1923-1929.

8. Wang Y, Chu Z, Qiu B, Liu C, Zhang Y (2006) Removal of naphthenic acids from vacuum fraction oil with an ammonia solution of ethylene glycol. Fuel 85 2489-2493.

9. Wan Abu Bakar WA, Ali R, Toemen S (2011) Catalytic methanation reaction over supported nickel-rhodium oxide for purification of simulated natural gas. Journal of Natural Gas Chemistry 20: 585-594. 